\title{
Identification of barley genetic regions influencing plant-microbe interactions and carbon cycling in soil
}

\author{
Lumbani Mwafulirwa (D) Elizabeth M. Baggs · Joanne Russell • \\ Christine A. Hackett • Nick Morley • Carla de la Fuente Cantó • \\ Eric Paterson
}

Received: 8 March 2021 / Accepted: 30 July 2021 / Published online: 26 August 2021

(C) The Author(s) 2021

\begin{abstract}
Purpose Rhizodeposition shapes soil microbial communities that perform important processes such as soil $\mathrm{C}$ mineralization, but we have limited understanding of the plant genetic regions influencing soil microbes. Here, barley chromosome regions affecting soil microbial biomass-C (MBC), dissolved organic$\mathrm{C}$ (DOC) and root biomass were characterised.

Methods A quantitative trait loci analysis approach was applied to identify barley chromosome regions
\end{abstract}

Responsible Editor: Feike A. Dijkstra

Supplementary Information The online version contains supplementary material available at https://doi. org/10.1007/s11104-021-05113-6.

L. Mwafulirwa $(\bowtie) \cdot$ E. M. Baggs

Global Academy of Agriculture and Food Security, The

Royal (Dick) School of Veterinary Studies, University

of Edinburgh, Midlothian EH25 9RG, UK

e-mail: 1.d.mwafulirwa@ reading.ac.uk

L. Mwafulirwa $\cdot$ E. Paterson

The James Hutton Institute, Craigiebuckler,

Aberdeen AB15 8QH, UK

Present Address:

L. Mwafulirwa

School of Agriculture, Policy and Development,

University of Reading, Reading RG6 6AR, UK

J. Russell

The James Hutton Institute, Invergowrie,

Dundee DD2 5DA, UK affecting soil MBC, soil DOC and root biomass. This was done using barley Recombinant Chromosome Substitution Lines (RCSLs) developed with a wild accession (Caesarea 26-24) as a donor parent and an elite cultivar (Harrington) as recipient parent.

Results Significant differences in root-derived MBC and DOC and root biomass among these RCSLs were observed. Analysis of variance using single nucleotide polymorphisms genotype classes revealed 16 chromosome regions influencing root-derived $\mathrm{MBC}$ and DOC. Of these chromosome regions, five on chromosomes $2 \mathrm{H}, 3 \mathrm{H}$ and $7 \mathrm{H}$ were highly significant and two on chromosome $3 \mathrm{H}$ influenced both rootderived MBC and DOC. Potential candidate genes influencing root-derived MBC and DOC concentrations in soil were identified.

\author{
C. A. Hackett \\ Biomathematics and Statistics Scotland, Invergowrie, \\ Dundee DD2 5DA, UK \\ N. Morley \\ School of Environmental Sciences, University of East \\ Anglia, Norwich NR4 7TJ, UK \\ C. de la Fuente Cantó \\ UMR DIADE, Institut de Recherche pour le \\ Développement and Université de Montpellier, \\ Montpellier, France
}


Conclusion The present findings provide new insights into the barley genetic influence on soil microbial communities. Further work to verify these barley chromosome regions and candidate genes could promote marker assisted selection and breeding of barley varieties that are able to more effectively shape soil microbes and soil processes via rhizodeposition, supporting sustainable crop production systems.

\section{Keywords Barley (Hordeum vulgare) · Crop} breeding · Plant-microbe interactions · Quantitative trait loci (QTL) mapping · Soil microbial biomass carbon $\cdot$ Sustainable agriculture

\section{Introduction}

Soil microbes mediate carbon (C) and organic matter cycling in soil, contributing a vital role for the regulation of $\mathrm{CO}_{2}$ emissions from soil (Prentice et al. 2001; $\mathrm{Li}$ et al. 2013) and nutrient release from soil organic matter (SOM) (Fontaine et al. 2011; Dijkstra et al. 2013; Alegria Terrazas et al. 2016). The soil microbial communities and their interactions with plants are impacted by the release of a range of compounds from living roots through root exudation, sloughed cells, mucilage and so on, collectively defined as rhizodeposition (Jones et al. 2004). These rhizodeposit compounds, in particular root exudates, are utilized by microbes as $\mathrm{C}$ sources to derive energy for their activity (Paterson 2003; Cheng and Kuzyakov 2005), with this resulting in the decrease or increase of SOM decomposition (Jenkinson et al. 1985; Kuzyakov et al. 2000; Yin et al. 2019). Indeed, it is known that the growth of plants can alter (via rhizodeposition) this microbially mediated SOM decomposition to varying extents (e.g. Cheng et al. 2003; Mwafulirwa et al. 2016,2021 ), with increases of up to $380 \%$ relative to unplanted soil reported by Cheng et al. (2003).

There is growing evidence that plant influences on soil microbial communities, and the functions they undertake, vary not only between plant species but also between individual genotypes within a single plant species. For example, studies by Aira et al. (2010), Bouffaud et al. (2012), Peiffer et al. (2013) and Walters et al. (2018) suggest that rhizosphere microbial community composition under maize is related to plant genotype. In barley, our previous findings (Mwafulirwa et al. 2016, 2017) and those of Pausch et al. (2016) are indicative that soil microbial activity and, in turn, the decomposition of SOM are also impacted by plant genotype. However, there is a lack of knowledge about the plant genetic regions and plant genes influencing these plant-microbe interactions. Identifying the plant genes influencing these interactions could, in particular, underpin the breeding of crop varieties to control microbially mediated soil processes (such as $\mathrm{C}$ mineralization). Hence, better understanding of the plant genes influencing (via rhizodeposition) soil microbes and SOM dynamics could help inform crop breeding to support sustainable agricultural production.

A major limitation for crop breeding to control soil processes, and in turn agricultural and/or environmental sustainability, is the current loss of beneficial plant traits associated with soil microbial interactions in the elite gene pool. This is because the development of modern crop cultivars through selection for yield and other beneficial crop plant traits (such as tolerance to biotic and abiotic stresses), usually under intensive chemical fertilizer applications to soil, have resulted in the loss of the plant genetic variation influencing plant-soil interactions (Tanksley and McCouch 1997; Wissuwa et al. 2009). To overcome this problem, others have proposed the use of wild relatives of crop species as donors of exotic germplasm to improve elite varieties. For example, Matus et al. (2003) developed a population of Recombinant Chromosome Substitution Lines (RCSLs) using wild barley Hordeum vulgare subsp. spontaneum (Caesarea 26-24) as a donor and Hordeum vulgare subsp. vulgare (Harrington, a North American malting cultivar) as the recurrent parent. Importantly, Caesarea 26-24 is adapted to specific soil conditions, in the view that it was collected in a dry and saline environment in Israel (Matus et al. 2003). This suggests that this accession could provide vital genes for regulating plant-soil interactions, especially for stress adaptation/tolerance promoting sustainable production. Our previous work investigating the impacts of plant intraspecific variation on SOM decomposition using a small number of these RCSLs showed that plant genotype influenced microbial activity and soil functioning (Mwafulirwa et al. 2016). The genetic composition of these RCSLs (Close et al. 2009; Comadran et al. 2012; de la Fuente Cantó et al. 2018) and 
a minimum set representing the entire genome of the wild donor parent (de la Fuente Cantó et al. 2018) have been previously determined using mapped single nucleotide polymorphisms (SNPs). The usefulness of minimum sets of introgression lines representing the entire genome of the donor parent for the detection of quantitative trait loci (QTL) effects and identification of novel exotic alleles is demonstrated by several QTL studies in crop plants, facilitating rapid screening of genetic variation for traits requiring detailed or complex phenotypic evaluations (Schmalenbach et al. 2009; de la Fuente Cantó et al. 2018). For example, Prudent et al. (2009) and Tripodi et al. (2020) used 20 and 39 tomato introgression lines, respectively. De la Fuente Cantó et al. (2018) used 28 barley RCSLs to evaluate allelic variation for important agronomic traits.

Here we used these 28 barley RCSLs, that together represent the whole genome of the wild donor Caesarea 26-24 in the genetic background of the elite variety Harrington, to assess the variation in selected root and soil microbe related traits, i.e. root biomass, dissolved organic-C (DOC) and microbial biomass-C (MBC). Previous studies (Blagodatskaya et al. 2009; Tian et al. 2012; Mwafulirwa et al. 2016) showed that soil DOC and MBC are strongly related to soil respiration rates, and thus to soil functioning. The specific objectives of the present study were to (i) determine the range of variation of the impacts of the barley RCSLs on DOC in soil solution and soil MBC using a ${ }^{13} \mathrm{C}-\mathrm{CO}_{2}$ isotopic labelling approach, and (ii) apply a QTL analysis approach with these RCSLs to identify the barley chromosome regions and potential candidate genes influencing soil DOC and MBC.

\section{Materials and methods}

\section{Soil type}

The soil was sampled from a conventionally managed field at Balruddery farm $\left(56.4837^{\circ} \mathrm{N}, 3.1314^{\circ} \mathrm{W}\right)$ near Dundee, Scotland, from a depth of $0-10 \mathrm{~cm}$ and was sieved to $<6 \mathrm{~mm}$ onsite before storing at $4{ }^{\circ} \mathrm{C}$ for one week. The soil was a sandy loam of Balrownie Series, Balrownie Association, as identified by Bell et al. (2014, unpublished), and had an organic matter content of 5.8\% (muffle furnace, $450{ }^{\circ} \mathrm{C}, 24 \mathrm{~h}$ ), $\mathrm{pH}$ of $6.0\left(\mathrm{H}_{2} \mathrm{O}\right)$ and water content $(\mathrm{w} / \mathrm{w})$ of $16.9 \%$. The field was planted with barley that was at vegetative (i.e. stem elongation) stage during soil sampling.

Plant materials and genotyping

Twenty-eight barley RCSLs developed using a wild donor (Caesarea 26-24, from a dry and saline region in Israel) and an elite cultivar (Harrington, a North American malting variety) as recipient parent via an advanced backcrossing strategy were used (Matus et al. 2003). These lines represent the minimum number covering the entire wild donor genome, and each line carries a small introgression of the wild barley genome in the predominantly elite background (Generation Challenge Program, unpublished). These lines were chosen because (i) they represent a unique source of genetic diversity to study plant-soil interactions (since they were derived using a wild barley accession adapted to unique soil and environmental conditions), and (ii) selected lines from this population showed differences in rhizodeposition-derived $\mathrm{C}$ and the respective impacts on $\mathrm{MBC}, \mathrm{DOC}$ and SOM mineralization, as observed in our earlier studies (Mwafulirwa et al. 2016, 2017). The genetic architecture of each line was determined from earlier work (de la Fuente Cantó et al. 2018), using the barley iSelect SNP chip (Comadran et al. 2012). Both parent genotypes (Caesarea 26-24 and Harrington) were used for phenotype evaluation, while only the elite parent Harrington was used as a control for genetic analysis.

Experimental setup and ${ }^{13} \mathrm{C}$ labelling

Soil was packed in 93 pots $(22.5 \mathrm{~cm} \times 5.5 \mathrm{~cm})$ to a bulk density of $1 \mathrm{~g} \mathrm{~cm}^{-3}$ and adjusted to $60 \%$ water holding capacity (the soil packing volume in each pot was $20.0 \mathrm{~cm} \times 5.5 \mathrm{~cm}$ ). After one week of soil stabilization in pots, soil solution samplers (Rhizon ${ }^{\mathrm{TM}}$ SMS, Rhizosphere Research Products, Wageningen, Netherlands) were inserted to $10 \mathrm{~cm}$ depth for DOC measurements. The system was left to stabilize to conditions used in the experiment for a further week before planting.

The barley plants were grown over 39 days without fertilizer addition to soil. Each pot was planted with one of the 30 genotypes (28 RCSLs plus parental 
genotypes), with one plant per pot, and fallow pots with soil only were included as a control treatment. These were replicated $(n=3)$ in a randomized complete block design under controlled environment conditions within a plant growth chamber (Conviron CG90; Winnipeg, Canada) at $22{ }^{\circ} \mathrm{C}$ and $70 \%$ relative humidity. Soil water content was maintained by adding deionized water on a mass basis twice a week. A $12 \mathrm{~h}$ daily photoperiod was set with $512 \mu \mathrm{mol} \mathrm{m} \mathrm{m}^{-2} \mathrm{~s}^{-1}$ PAR within the chamber. Watering was done during the dark period to avoid disruption to the labelling atmosphere.

Labelling plants with ${ }^{13} \mathrm{C}-\mathrm{CO}_{2}$ started at the seedling growth stage, one week after sowing seeds. This was achieved by passing a continuous flow of ${ }^{13} \mathrm{C}$-enriched $\mathrm{CO}_{2}\left(20\right.$ atom $\left.\%{ }^{13} \mathrm{C}\right)$ through the plant growth chamber continuously over the experiment period, which was derived by blending $\mathrm{CO}_{2}$-free air routed via pressure swing adsorption $\mathrm{CO}_{2}$ scrubber unit (Parker Balston, Haverhill, USA) with 99 atom\% excess ${ }^{13} \mathrm{C}-\mathrm{CO}_{2}$ (Sercon Ltd., Cheshire, UK) and $\mathrm{CO}_{2}$ from a standard $\mathrm{CO}_{2}$ cylinder (BOC, Worsley, UK) via Brooks thermal mass flow controllers (Flotech Solutions Ltd., Stockport, UK).

\section{Phenotyping}

Measurement of DOC was done at 30d and 39d (harvest point), $\mathrm{MBC}$ was measured at $39 \mathrm{~d}$, and plant biomass (separated into root and shoot biomass) was quantified at 39d. For DOC sampling, vacuum sealed $10 \mathrm{~mL}$ bottles were connected to Rhizon soil solution samplers via needle ends and left overnight. The vacuum allowed the soil solution to be drawn into the bottle. Bottles were detached and the collected solutions were kept frozen until they could be analysed for total organic C (TOC) concentration (Shimadzu TOC analyser, Japan) and ${ }^{13} \mathrm{C}$-enrichment of this TOC. Soil solution TOC was assumed to represent total DOC. The ${ }^{13} \mathrm{C}$-enrichment of DOC was determined using a method described by Garcia-Pausas and Paterson (2011). In brief, the frozen soil solutions were defrosted and sufficient solutions to contain a minimum of $20 \mu \mathrm{g} \mathrm{C}$ and a maximum of $60 \mu \mathrm{g}$ $\mathrm{C}$ per sample, as established from previous TOC analysis of the solutions, were dispensed into mufflefurnanced $12 \mathrm{~mL}$ Exetainer vials (Labco Ltd., High Wycombe, UK). Maximum volume in the Exetainers was $4 \mathrm{~mL}$, and deionized water was added to reach the $4 \mathrm{~mL}$ volume if a lesser volume was taken. An aliquot of $100 \mu \mathrm{L}$ of $1.3 \mathrm{M}$ phosphoric acid was added to each sample to remove dissolved inorganic $\mathrm{C}$ from the solution. The soil solutions were left with caps off for one hour, following which the vials were capped and flushed with $\mathrm{CO}_{2}$-free air on the gas bench. To evolve organic $\mathrm{C}$ as $\mathrm{CO}_{2}$, an aliquot of $100 \mu \mathrm{L} 1.05 \mathrm{M}$ sodium persulphate was injected into each solution sample through the rubber septum of the vial-cap. The samples were then heated on a dry block at $90{ }^{\circ} \mathrm{C}$ for $30 \mathrm{~min}$ to release $\mathrm{CO}_{2}$. The $\mathrm{CO}_{2}$ released from the soil solution was then transferred to pre-evacuated $\mathrm{N}_{2}$ flush-filled Exetainer vials using a syringe with a flow control valve. The ${ }^{13} \mathrm{C}$-enrichment of the $\mathrm{CO}_{2}$ sample was determined on a Delta ${ }^{\text {PLUS }}$ Advantage isotope ratio mass spectrometer via an interfaced Gasbench II unit (both Thermo Finnigan, Bremen, Germany). The measured ${ }^{13} \mathrm{C}$-enrichment (atom $\%{ }^{13} \mathrm{C}$ ) of soil solutions were used to separate root-derived DOC $\left(\mathrm{DOC}_{\text {plant }}\right)$ and SOM-derived DOC ( $\left.\mathrm{DOC}_{\text {soil }}\right)$ proportions of total DOC ( $\left.\mathrm{DOC}_{\text {total }}\right)$ following Eqs. 1 and 2 (Garcia-Pausas and Paterson 2011).

$$
\begin{array}{r}
\mathrm{DOC}_{\text {plant }}=\mathrm{DOC}_{\text {total }}\left(\text { atom } \%{ }^{13} \mathrm{C}_{\text {control }}-\text { atom } \%{ }^{13} \mathrm{C}_{\text {total }}\right) \\
/\left(\text { atom } \%{ }^{13} \mathrm{C}_{\text {control }}-\text { atom } \%{ }^{13} \mathrm{C}_{\text {plant }}\right)
\end{array}
$$

$\mathrm{DOC}_{\text {soil }}=\mathrm{DOC}_{\text {total }}-\mathrm{DOC}_{\text {plant }}$

where atom $\%{ }^{13} \mathrm{C}_{\text {control }}$ is the mean atom $\%{ }^{13} \mathrm{C}$ of DOC measured in the unlabelled fallow control treatments and atom $\%{ }^{13} \mathrm{C}_{\text {total }}$ is the measured atom $\%$ ${ }^{13} \mathrm{C}$ value of sample total DOC. Atom $\%{ }^{13} \mathrm{C}_{\text {plant }}$ is the atom $\%{ }^{13} \mathrm{C}$ value of the plant tissue (described below).

At harvest, soils were re-wetted to initial moisture level by adding deionized water. Plant shoots were harvested by cutting at the soil surface. Roots were carefully removed from soil (shaking off most of the adhering soil) and put in separate containers then washed with deionized water. The harvested plant shoot and root fractions were taken for freeze-drying. The soil was harvested as one fraction, considering that the soil was densely colonised by roots. The fresh harvested soil was thoroughly mixed by hand and immediately stored at $4{ }^{\circ} \mathrm{C}$ for subsequent analyses of soil MBC. The dry weights of root and shoot fractions were used to quantify root and shoot biomass, and total plant biomass was calculated as root 
plus shoot biomass. Dried root and shoot samples were ball-milled (Retsch Ball Mill, model MM2000) and analysed for ${ }^{13} \mathrm{C}$-enrichment on a Flash EA 1112 Series Elemental Analyser connected via a Conflo III to a Delta ${ }^{\text {Plus }}$ XP isotope ratio mass spectrometer (all Thermo Finnigan, Bremen, Germany).

The fresh soil samples were used to determine the soil MBC concentration, within $24 \mathrm{~h}$ following harvest. Two sub samples of the fresh harvested soil were used for MBC analysis. MBC was determined by the chloroform fumigation-extraction method (Vance et al. 1987), where fresh fumigated and nonfumigated soil samples (equivalent $12.5 \mathrm{~g}$ dry soil) were extracted with $50 \mathrm{~mL}$ of $0.5 \mathrm{M} \mathrm{K}_{2} \mathrm{SO}_{4}$ solution. Organic $\mathrm{C}$ of the extracts was analysed on a TOC Analyser 700 (Corporation College Station, TX). MBC was calculated as the difference between organic $\mathrm{C}$ in the paired fumigated and non-fumigated extracts using a conversion factor $k_{\mathrm{EC}}$ of 0.45 (Eq. 3) (Joergensen 1996).

$\mathrm{MBC}=\left(\mathrm{TOC}_{\text {Fumigated }}-\mathrm{TOC}_{\text {Non-fumigated }}\right) / k_{\mathrm{EC}}$

where TOC $_{\text {Fumigated }}$ is TOC of fumigated soil sample and $\mathrm{TOC}_{\text {Non-fumigated }}$ is TOC of the paired nonfumigated soil sample. We further determined the ${ }^{13} \mathrm{C}$-enrichment of $\mathrm{MBC}$ using a method outlined above for determining the ${ }^{13} \mathrm{C}$-enrichment of DOC (Garcia-Pausas and Paterson 2011) and calculated the fractions of MBC derived from plant and SOM using Eqs. 1 and 2.

\section{Statistical and genetic analyses}

The software package GenStat (Eighteenth Edition, VSN International Ltd) was used for all statistical analyses. Repeated-measures analysis of variance (ANOVA) was used to assess the effects of barley genotype and sampling date on soil solution DOC (i.e. total DOC, root-derived DOC and SOM-derived DOC), with barley genotype as the fixed factor and sampling date as the repeated factor. In addition, oneway ANOVA was used to test for differences in soil MBC and plant biomass (including root and shoot biomass) among genotypes at harvest point. Where statistically significant $(p<0.05)$ genotype effects were found, the least significant difference (LSD) was used to assess differences between individual means.
For identification of barley chromosome regions influencing the observed phenotypes (i.e. root-derived MBC, root-derived DOC and root biomass, all at 39d), one-way ANOVA was used to analyse the genotype means for each trait to test whether these were related to the genotype for each SNP on the map, with 235 SNPs used in the analysis. Each of these markers represents a block of contiguous SNPs that were found polymorphic for the same RCSLs. We removed redundant markers from the initial group of 1848 SNPs used to characterise the RCSLs. Nevertheless, the mapping information for the group of SNPs within each block was considered to define the QTL regions as explained in de la Fuente Cantó et al. (2018). We present all marker effects that are significant with $p<0.05$, but we focus on the most significant ones with $p<0.01$ to take into account that multiple markers have been tested. The relative performance of individual RCSLs $\left(\mathrm{RP}_{\mathrm{RCSL}}\right)$, in comparison to the lines with the genotype of the elite parent Harrington, was calculated following Eq. 4. Caesarea 26-24 (donor parent) was not used in the genetic analysis.

$\mathrm{RP}_{\mathrm{RCSL}}=\left[\left(\mathrm{M}_{\mathrm{RCSL}}-\mathrm{M}_{\text {Harrington }}\right) / \mathrm{M}_{\text {Harrington }}\right] \times 100$

where $\mathrm{M}_{\mathrm{RCSL}}$ is the trait mean of the RCSL genotypes and $\mathrm{M}_{\text {Harrington }}$ is the trait mean of the lines with the genotype of the elite parent.

Where two phenotypes or traits were found to be influenced by the same chromosome region (i.e. multiple marker effects), Pearson correlation was used to determine the relationship between those two phenotypes. Pearson correlation was also applied to determine the relationship between root biomass and root-derived MBC.

\section{Identification of candidate genes}

Genes which are located within the introgressed chromosome regions that span the observed significant markers and their physical positions were determined from the gene database Barlex (https://apex.ipk-gater sleben.de/apex/f?p=284:10) and a map-based barley genome assembly with high-confidence genes (Mascher et al. 2017). Based on gene functional annotation, in relation to root-derived $\mathrm{MBC}$ and DOC subsets of potential candidates were identified. 


\section{Results}

Phenotypes

The barley plants were at vegetative (i.e. tillering) stage at the harvest date, $39 \mathrm{~d}$ after planting, and showed no signs of stress (i.e. pest or pathogen infestation, nor nutrient or water deficiency). Plant tissue ${ }^{13} \mathrm{C}$-enrichment ranged from 2.06 to 2.17 atom $\%{ }^{13} \mathrm{C}$, and did not significantly differ among genotypes. Statistically significant $(p<0.05)$ differences in root biomass (Fig. 1) and shoot biomass (Fig. S1) among the genotypes were observed.

For soil related characteristics, ANOVA (Tables 1 and S1) showed significant $(p<0.05)$

Fig. 1 Root biomass (dry weight) measured at $39 \mathrm{~d}$ for 28 barley recombinant chromosome substitution lines (RCSLs) and parental genotypes Caesarea 26-24 and Harrington. Values are means $(n=3)$. Bars show \pm one standard error of the mean. Significant differences $(p<0.05)$ among barley genotypes were estimated using ANOVA

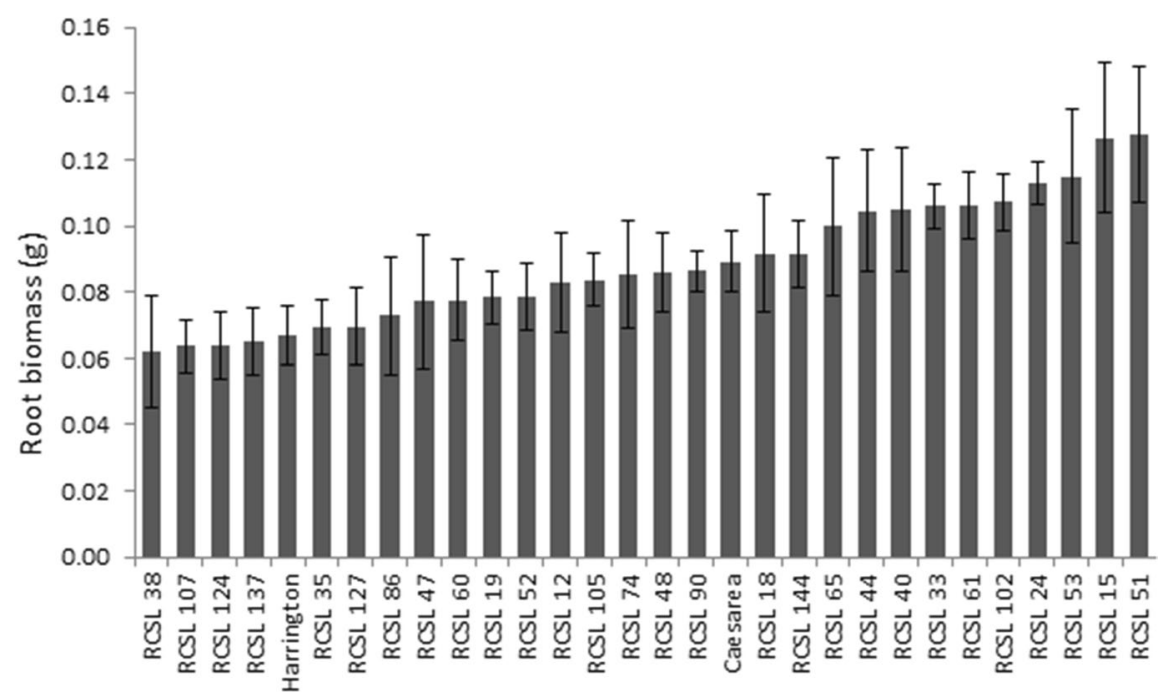

Table 1 Analysis of variance for barley plant biomass, soil microbial biomass carbon (MBC) and dissolved organic carbon (DOC) in soil solution

\begin{tabular}{|c|c|c|c|}
\hline Parameter & Source of variation & df & $p$ value \\
\hline Root biomass (g) & Barley genotype & 29 & 0.041 \\
\hline Shoot biomass (g) & Barley genotype & 29 & 0.001 \\
\hline Total plant biomass $(\mathrm{g})$ & Barley genotype & 29 & 0.019 \\
\hline Root-derived MBC ( $\mathrm{mg} \mathrm{C} \mathrm{kg}^{-1}$ soil) & Barley genotype & 29 & 0.013 \\
\hline SOM-derived MBC (mg C kg-1 soil) & Barley genotype & 29 & 0.887 \\
\hline Total MBC (mg C kg${ }^{-1}$ soil) & Barley genotype & 29 & 0.854 \\
\hline \multirow[t]{3}{*}{ Root-derived DOC (mg C L ${ }^{-1}$ soil solution) } & Barley genotype & 29 & 0.001 \\
\hline & Sampling time & 1 & $<0.001$ \\
\hline & Genotype $\times$ time & 29 & 0.006 \\
\hline \multirow[t]{3}{*}{ SOM-derived DOC (mg C L ${ }^{-1}$ soil solution) } & Barley genotype & 29 & 0.257 \\
\hline & Sampling time & 1 & $<0.001$ \\
\hline & Genotype $\times$ time & 29 & 0.984 \\
\hline \multirow[t]{3}{*}{ Total DOC (mg C L ${ }^{-1}$ soil solution) } & Barley genotype & 29 & 0.357 \\
\hline & Sampling time & 1 & $<0.001$ \\
\hline & Genotype $\times$ time & 29 & 0.974 \\
\hline
\end{tabular}

Significant $p$ values $(p<0.05)$ are shown in bold

DOC was measured at 30d and 39d, while plant biomass and MBC were measured at 39d

$d f$ degrees of freedom, SOM soil organic matter 
Fig. 2 Root-derived microbial biomass- $\mathrm{C}$ (MBC) measured at 39d (a) and root-derived dissolved organic-C (DOC) measured at 30d and 39d (b) for 28 barley recombinant chromosome substitution lines (RCSLs) and parental genotypes Caesarea 26-24 and Harrington. Values are means $(n=3)$. Bars show \pm one standard error of the mean. Significant differences $(p<0.05)$ among barley genotypes and between sampling times were estimated using ANOVA
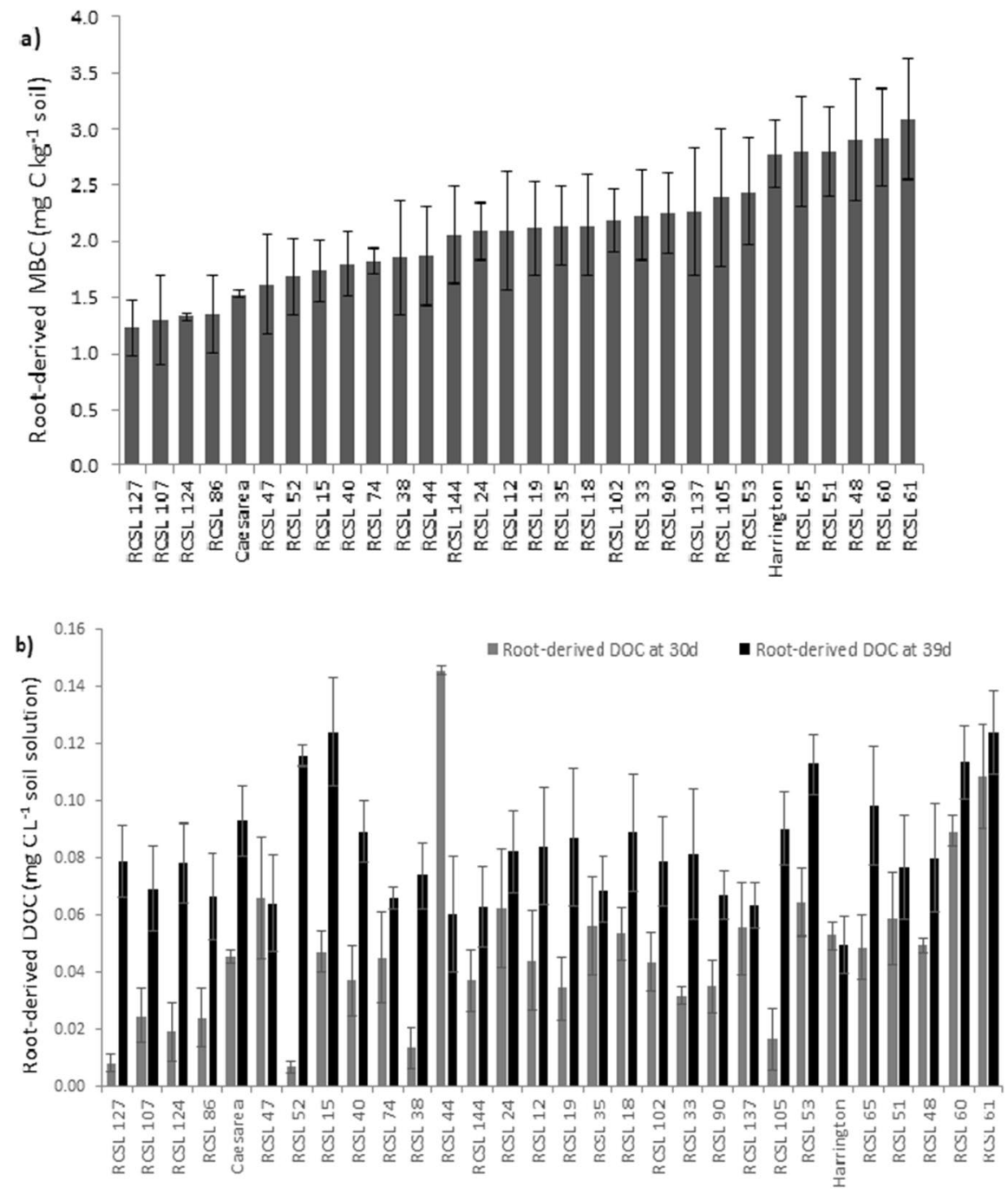

variation among genotypes for root-derived $\mathrm{MBC}$ (Fig. 2a) and root-derived DOC (Fig. 2b). The largest root-derived $\mathrm{MBC}$, measured at $39 \mathrm{~d}$, was determined as $3.1 \mathrm{mg} \mathrm{C} \mathrm{kg}^{-1}$ soil, while the smallest root-derived $\mathrm{MBC}$ was estimated as $1.2 \mathrm{mg} \mathrm{C}$ $\mathrm{kg}^{-1}$ soil. The estimated root-derived DOC among genotypes ranged from 0.01 to $0.15 \mathrm{mg} \mathrm{C} \mathrm{L}^{-1}$ soil solution $\left(0.05 \mathrm{mg} \mathrm{C} \mathrm{L}^{-1}\right.$ soil solution average) at 30d and $0.05-0.12 \mathrm{mg} \mathrm{C} \mathrm{L}^{-1}$ soil solution $(0.08 \mathrm{mg}$ $\mathrm{C} \mathrm{L} \mathrm{L}^{-1}$ soil solution average) at $39 \mathrm{~d}$, showing an increasing trend over time. There were no significant differences (Table 1) in total or SOM-derived MBC and total or SOM-derived DOC among the genotypes. Average SOM-derived $\mathrm{MBC}$ and average total MBC were 68.20 and $70.30 \mathrm{mg} \mathrm{C} \mathrm{kg}^{-1}$ soil, respectively. SOM-derived DOC decreased from an average of $19.97 \mathrm{mg} \mathrm{C} \mathrm{L}^{-1}$ soil solution at 30d to $17.11 \mathrm{mg} \mathrm{C} \mathrm{L}^{-1}$ soil solution at $39 \mathrm{~d}$, while total DOC decreased from an average of $20.12 \mathrm{mg}$ $\mathrm{C} \mathrm{L}^{-1}$ soil solution at $30 \mathrm{~d}$ to $17.20 \mathrm{mg} \mathrm{C} \mathrm{L}^{-1}$ soil solution at $39 \mathrm{~d}$.

Pearson correlation showed a moderate, positive relationship between root-derived DOC and rootderived MBC $(r=0.52 ; p<0.001)$ (Fig. 3a) and a low, positive correlation between root biomass and root-derived MBC ( $r=0.44 ; p<0.001)$ (Fig. 3b).

Genetic marker effects and annotated genes

In total, 16 statistically significant $(p<0.05)$ marker effects (including two multiple marker effects) for root-derived $\mathrm{MBC}$ and root-derived DOC, both at 
Fig. 3 Correlation between root-derived dissolved organic-C (DOC) and root-derived microbial biomass-C (MBC) (a) and that between root biomass and root-derived $\mathrm{MBC}$ (b), all measured at 39d, for 28 barley Recombinant Chromosome Substitution Lines (RCSLs) and parental genotypes Caesarea 26-24 and Harrington. Each point in the scatter plot represents paired (root-derived DOC and $\mathrm{MBC}$ ) individual pot measurements
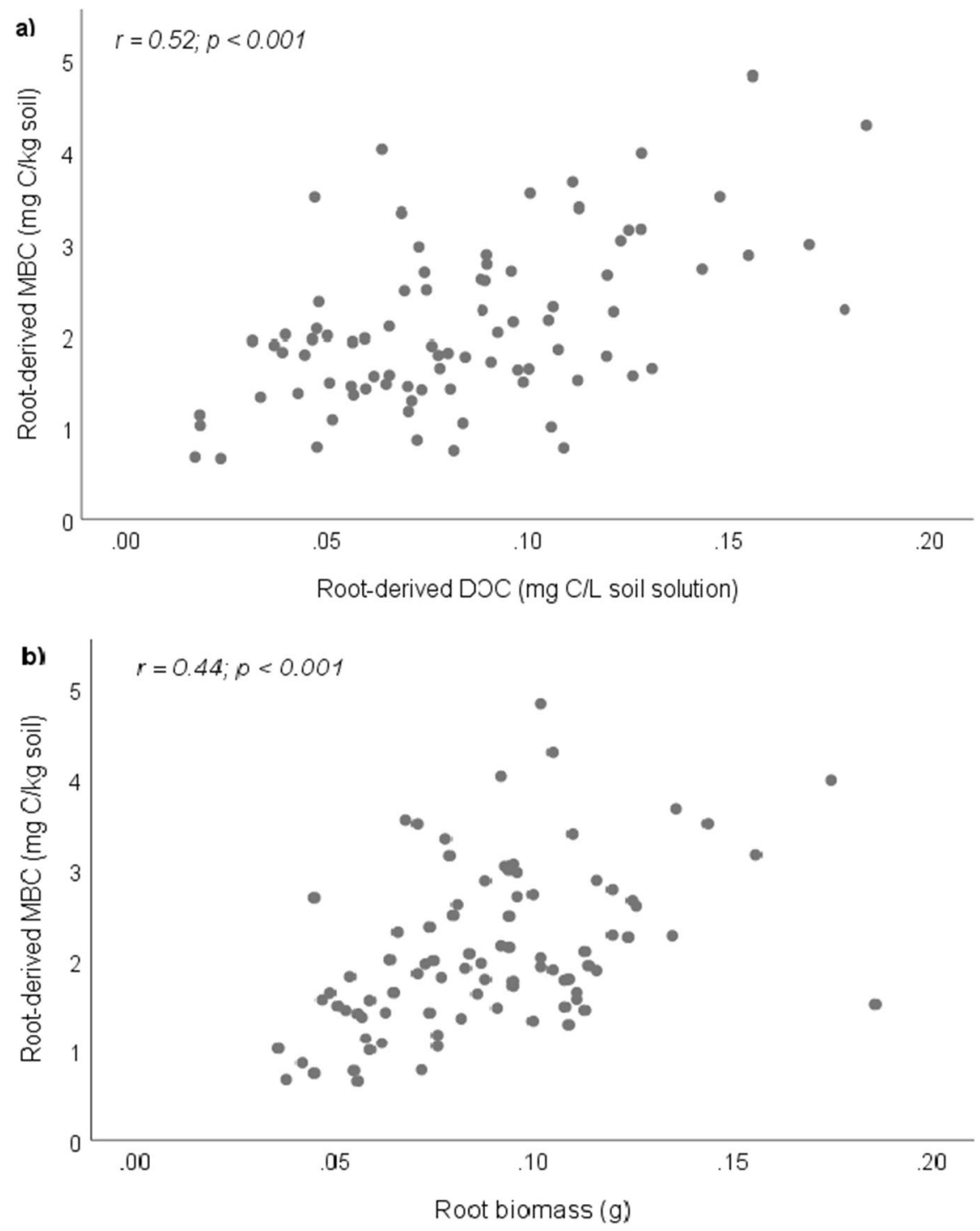

39d, were detected (Table 2). Root-derived MBC had the highest number of significant marker effects. These marker effects were found on chromosomes $2 \mathrm{H}, 3 \mathrm{H}, 4 \mathrm{H}$ and $7 \mathrm{H}$. Five of the markers (12_31293, SCRI_RS_129857 and SCRI_RS_171032 on 2H, SCRI_RS_183659 on 3H and 11_21437 on 7H, representing block regions containing 39, 64, 33, 248 and 118 annotated and unknown genes, respectively) were highly significant $(p \leq 0.01)$ (Table 2$)$. Several genes encoding proteins involved in metabolite transport (e.g. HORVU2Hr1G091190.3 for sugar transporter 9 around $647,278,826-647,282,664$ bp on $2 \mathrm{H}$ and HORVU3Hr1G074290.4 for MATE efflux family protein around $557,949,641-557,952,693 \mathrm{bp}$ on $3 \mathrm{H}$ ) were found around these marker positions. Furthermore, genes/proteins involved in gene expression regulation (e.g. HORVU2Hr1G090640.1 for TCP family transcription factor around 645,146,133-645,147,494 bp and HORVU2Hr1G092030.14 for NAC domain protein around $650,452,493-650,457,428$ bp on $2 \mathrm{H}$ ) and metabolite synthesis (e.g. HORVU3Hr1G075870.1 for photosystem II reaction center $\mathrm{W}$ protein around $566,531,044-566,534,103$ bp on $3 \mathrm{H}$ and HORVU7Hr1G012380.5 for starch synthase 2 around $17,089,868-17,094,404$ bp on $7 \mathrm{H}$ ) were found on these chromosome regions (Table S2). On one chromosome region, at marker SCRI_RS_200957 on $4 \mathrm{H}$ (position 76.3-78.5 cM, representing a region 


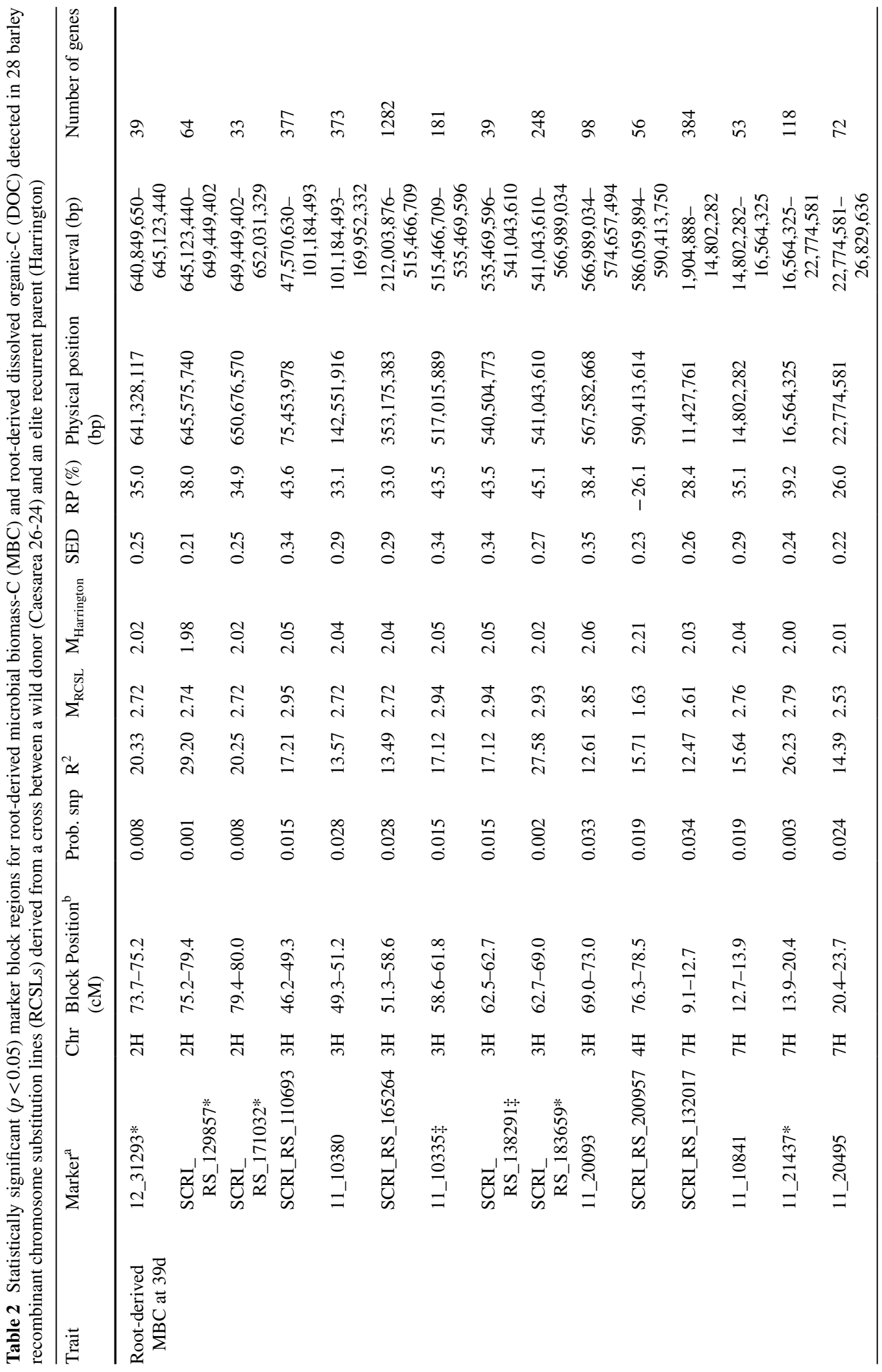




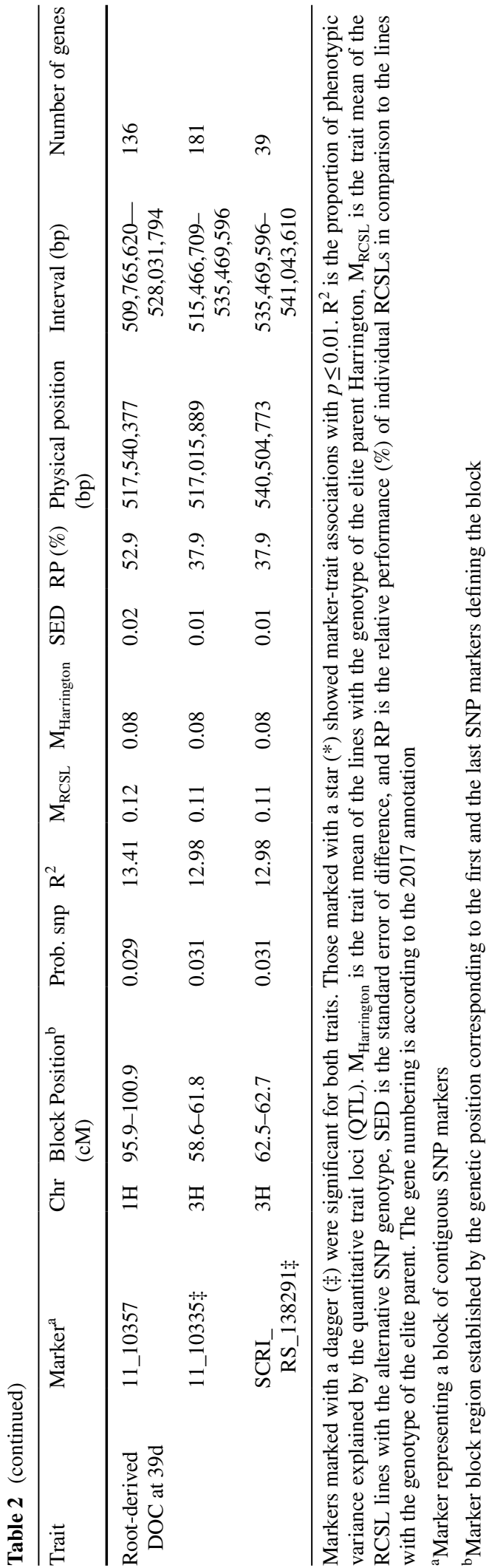

spanning 586,059,894-590,413,750 bp containing 56 genes), the exotic (Caesarea 26-24) introgression decreased the root-derived MBC (by 26\%). For all other significant markers or chromosome regions, exotic introgressions increased the root-derived MBC by 26-45\% (Tables 2 and 3). Three significant marker effects were detected for root-derived DOC, one on chromosome $1 \mathrm{H}$ and two on chromosome $3 \mathrm{H}$. Here, the two markers identified on chromosome 3H (11_10335 on position 58.6-61.8 cM spanning 515,466,709-535,469,596 bp with 181 genes including the gene (HORVU3Hr1G068450.2) encoding trehalose-6-phosphate (T6P) phosphatase, and SCRI_RS_138291 on position 62.5-62.7 cM spanning $535,469,596-541,043,610$ bp with 39 genes) were also detected for root-derived MBC (Tables 2 and S2). For these two multiple marker effects, exotic introgressions increased root-derived DOC and rootderived $\mathrm{MBC}$ by 38 and $44 \%$, respectively.

Seven statistically significant $(p<0.05)$ markers were identified for root biomass (Table 4). These marker effects were found on chromosomes $2 \mathrm{H}, 3 \mathrm{H}$, $5 \mathrm{H}$ and $7 \mathrm{H}$, with the exotic introgressions increasing root biomass by $29-36 \%$.

A barley genetic map showing statistically significant markers identified for root-derived $\mathrm{MBC}$, rootderived DOC and root biomass is presented in Fig. 4.

\section{Discussion}

Phenotypic evaluation

Analysis of soil microbial biomass showed that concentration of root-derived MBC varied among genotypes. Total MBC and its proportion derived from SOM did not significantly differ among the genotypes. The lack of significant differences in total MBC among genotypes (notwithstanding that rootderived $\mathrm{MBC}$ varied among the genotypes) may suggest that barley rhizodeposition impacted microbial activity, including microbial use of root-derived $\mathrm{C}$, rather than microbial growth. This assumption agrees with Shahzad et al. (2015) who showed that root exudation by grassland species could stimulate microbial activity without increasing microbial biomass. It also concurs with Paterson et al. (2008) who suggested that smaller $\mathrm{C}$ inputs to soil may not cause significant 


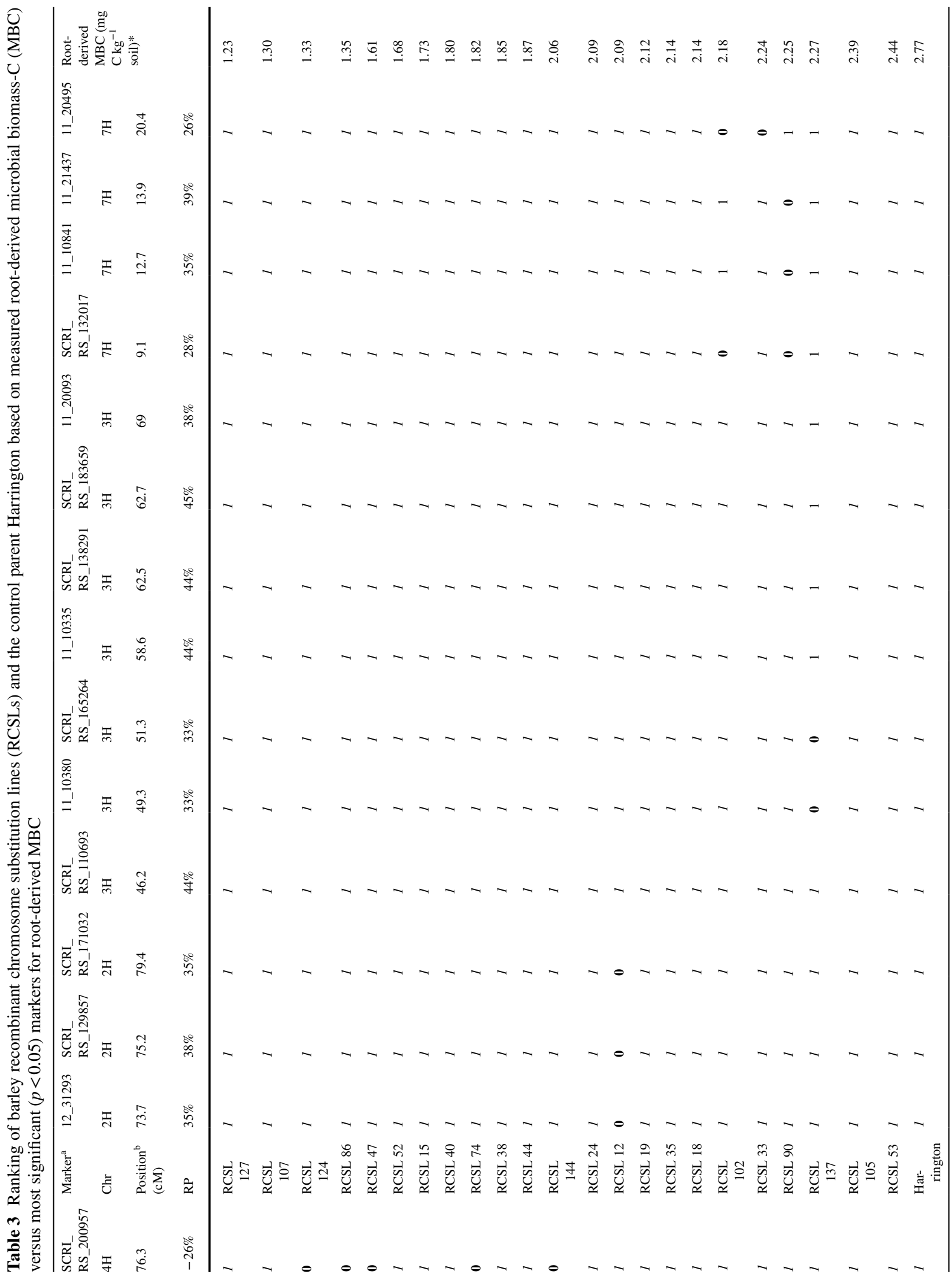




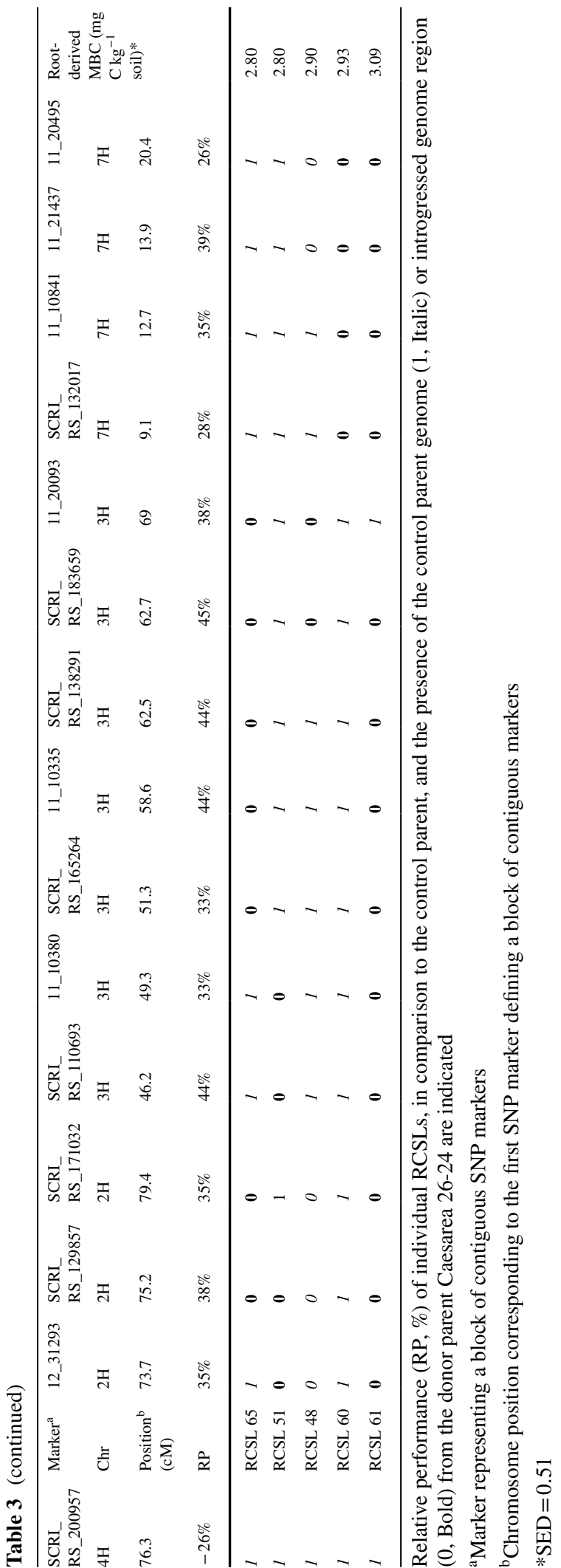

changes in the microbial population, and would be processed by those organisms already present in soil. Moreover, this result is consistent with our previous study (Mwafulirwa et al. 2016) where a small number of genotypes from the same barley population did not vary in total $\mathrm{MBC}$ and $\mathrm{SOM}$-derived $\mathrm{MBC}$ but varied in root-derived $\mathrm{MBC}$, root-derived $\mathrm{CO}_{2}-\mathrm{C}$, SOMderived $\mathrm{CO}_{2}-\mathrm{C}$ and total $\mathrm{CO}_{2}-\mathrm{C}$ surface soil fluxes.

The present results also did not show genotype effects on SOM-derived DOC in soil solutions sampled at $30 \mathrm{~d}$ and $39 \mathrm{~d}$. However, the fraction of total DOC derived from roots varied among the genotypes at both sampling dates. Likewise, these results corroborate our earlier work (Mwafulirwa et al. 2016) where root-derived DOC varied among genotypes (that were selected from the barley population used in the present study) while SOMderived DOC also did not vary among the genotypes. Root-derived DOC increased over time, consistent with plant growth increasing root inputs to soil. In contrast, SOM-derived DOC and total DOC decreased over time, in line with depletion of the available SOM stock. In the present study, it was also noted that concentrations of root-derived DOC among genotypes at $30 \mathrm{~d}$ did not correlate with concentrations at $39 \mathrm{~d}$. This could be explained by restricted root growth because of the use of small pots, in which root growth rates may change with changes in soil nutrients (Marschner 1995) or when all the readily available soil has been explored (Garnett et al. 2009). As such, it is likely that the root-to-soil ratio for individual genotypes varied between the two sampling dates (i.e. $30 \mathrm{~d}$ and 39d). This potentially affected exudation amounts and thus root-derived DOC concentrations in the soil solutions between those time points. Nevertheless, the pattern of root-derived DOC among genotypes at $30 \mathrm{~d}$ was consistent with that observed in our previous work using a small number of RCSLs (Mwafulirwa et al. 2016).

Wild barley Caesarea 26-24 had a larger root biomass relative to modern barley Harrington. Indeed, detection of marker effects in the RCSLs (discussed below) showed that the wild barley genome increased root biomass (Table 4). These findings are in agreement with the general understanding that wild barley accessions have an inherent ability to develop vigorous or extensive rooting systems (White et al. 2009; Naz et al. 2014), 
Table 4 List of seven statistically significant $(p<0.05)$ marker block regions for root biomass detected in 28 barley recombinant chromosome substitution lines (RCSLs) derived from a cross between a wild donor (Caesarea 26-24) and an elite recurrent parent (Harrington)

\begin{tabular}{|c|c|c|c|c|c|c|c|c|}
\hline Marker $^{\mathrm{a}}$ & $\mathrm{Chr}$ & Block position $^{\mathrm{b}}(\mathrm{cM})$ & Prob. snp & $\mathrm{R}^{2}$ & $\mathrm{M}_{\mathrm{RCSL}}$ & $\mathrm{M}_{\text {Harrington }}$ & SED & $\mathrm{RP}(\%)$ \\
\hline 11_20173 & $2 \mathrm{H}$ & $38.1-40.8$ & 0.018 & 15.95 & 0.11 & 0.09 & 0.01 & 31.6 \\
\hline SCRI_RS_14801 & $2 \mathrm{H}$ & $48.4-53.8$ & 0.014 & 17.39 & 0.11 & 0.09 & 0.01 & 29.1 \\
\hline SCRI_RS_119379 & $3 \mathrm{H}$ & $3.1-8.9$ & 0.016 & 16.57 & 0.11 & 0.09 & 0.01 & 28.5 \\
\hline SCRI_RS_110693 & $3 \mathrm{H}$ & $46.2-49.3$ & 0.028 & 13.63 & 0.12 & 0.09 & 0.01 & 35.3 \\
\hline SCRI_RS_205235 & $5 \mathrm{H}$ & $55.7-71.7$ & 0.017 & 16.31 & 0.11 & 0.09 & 0.01 & 31.9 \\
\hline SCRI_RS_120015* & $7 \mathrm{H}$ & $134.2-140.4$ & 0.007 & 22.02 & 0.12 & 0.09 & 0.01 & 35.1 \\
\hline SCRI_RS_158599* & $7 \mathrm{H}$ & $140.4-140.9$ & 0.006 & 22.14 & 0.12 & 0.09 & 0.01 & 36.4 \\
\hline
\end{tabular}

Those marked with a star (*) showed marker-trait associations with $p \leq 0.01 . \mathrm{R}^{2}$ is the proportion of phenotypic variance explained by the quantitative trait loci (QTL). $\mathrm{M}_{\text {Harrington }}$ is the trait mean of the lines with the genotype of the elite parent Harrington, $\mathrm{M}_{\mathrm{RCSL}}$ is the trait mean of the RCSL lines with the alternative SNP genotype, SED is the standard error of difference, and RP is the relative performance (\%) of individual RCSLs in comparison to the lines with the genotype of the elite parent

${ }^{a}$ Marker representing a block of contiguous SNP markers

${ }^{\mathrm{b}}$ Marker block region established by the genetic position corresponding to the first and the last SNP markers defining the block
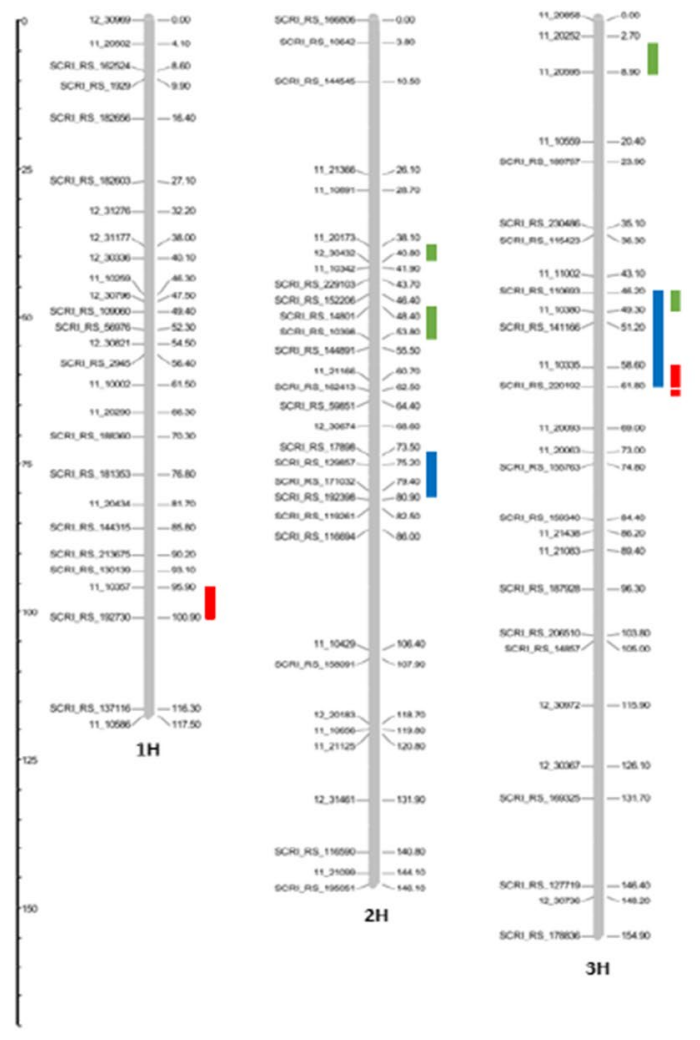

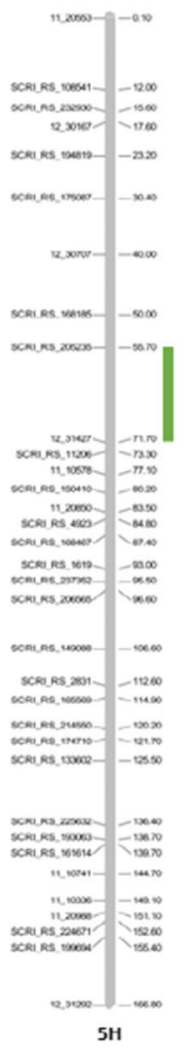

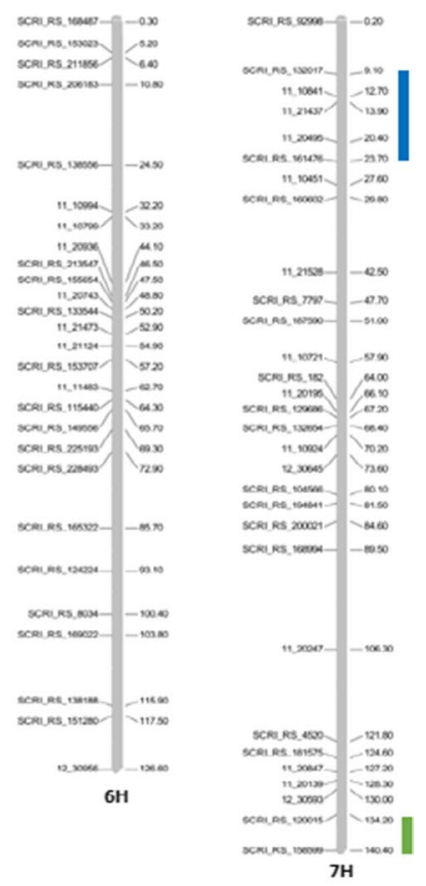

Fig. 4 Barley genetic map showing chromosome regions found associated with root-derived $\mathrm{MBC}$ at 39d (blue bars), root-derived DOC at 39d (red bars) and root biomass (green bars). Marker names and genetic positions (cM) correspond to the iSelect SNP chip (Comadran et al. 2012) colour figure online 
that lead to greater contact between roots and soil, which in turn enhance water uptake, and thus tolerance to drought (Gahoonia and Nielsen 2004). Naz et al. (2014) also found a vigorous root system in wild barley ISR42-8 in comparison to modern barley Scarlett under control and drought conditions.

Chromosome regions and potential candidate genes influencing soil related traits

Identification of marker effects revealed 16 chromosome regions influencing root-derived $\mathrm{MBC}$ and root-derived DOC in soil. Of these, five chromosome regions on marker positions $73.7-75.2 \mathrm{cM}$, 75.2-79.4 cM (peak marker-trait association) and $79.4-80.0 \mathrm{cM}$ on chromosome $2 \mathrm{H}$ (considered as single QTL), 62.7-69.0 $\mathrm{cM}$ on chromosome $3 \mathrm{H}$ and 13.9-20.4 cM on chromosome $7 \mathrm{H}$ showed stronger effects. The genes associated with proteins involved in metabolite synthesis (e.g. the starch synthase 2, Patterson et al. 2018) and transport (e.g. the sugar transporter 9 and the MATE efflux family protein, dos Santos et al. 2017; Julius et al. 2017) and gene expression regulation specific for roots (e.g. the TCP family transcription factor and the NAC domain protein, Janiak et al. 2019) may be potential candidate genes that influenced the variations found for rootderived $\mathrm{MBC}$ and DOC.

For one marker localised on chromosome $4 \mathrm{H}$, position 76.3-78.5 cM, the wild barley genome introgression decreased root-derived MBC. This is in line with the phenotype data considering that the wild barley (Caesarea 26-24) (Fig. 2a) and the RCSLs with the wild barley genome on this chromosome region (Table 3) were associated with smaller root-derived MBC, relative to modern barley (Harrington). Therefore, this result suggests that Caesarea 26-24 harbours alleles on chromosome $4 \mathrm{H}$ that influence microbial use of root-derived $\mathrm{C}$ and its flow through the microbial biomass. All other detected marker effects for root-derived $\mathrm{MBC}$ showed that the wild barley genome introgressions increased root-derived MBC, but this was in contrast to the observed phenotype (discussed above). This, however, may be indicative of interactive allele or loci effects (Li et al. 2010), or that those effects on MBC were conferred by the modern barley (Harrington) genome. For DOC, the detected marker effects showed that the wild barley genome introgressions increased root-derived
DOC. Here, all the detected marker effects (on positions 95.9-100.9 $\mathrm{cM}$ on chromosome $1 \mathrm{H}$ and 58.6-61.8 cM and 62.5-62.7 cM on chromosome $3 \mathrm{H}$ ) were in agreement with the phenotype data. This is because the wild genotype Caesarea 26-24 was associated with larger root-derived DOC concentration (at 39d) in comparison to the modern genotype Harrington. As such, these results suggest that the wild barley genotype Caesarea 26-24 carries alleles that influence root-derived DOC on those three chromosome regions. This assumption is in line with the gene encoding T6P found on chromosome $3 \mathrm{H}$, which could be a candidate gene influencing root $\mathrm{C}$ deposition and, in turn, root-derived DOC and MBC concentrations in soil. The T6P signalling system is a major regulator of resource allocation (e.g. $\mathrm{C}$ allocation and utilization in plants) and has been implicated in several processes in crop plants including assimilate partitioning and source-sink relationships (Paul et al. 2018, 2020). To our knowledge, this study is the first to demonstrate the localization of the barley genetic influence on soil MBC and DOC, and thus on soil $\mathrm{C}$ cycling.

The two genome regions on chromosome $3 \mathrm{H}$ (discussed above, although this could be considered a single QTL) affected both root-derived DOC and root-derived MBC. This is consistent with the relationship between these two traits, as determined by Pearson correlation analysis, being significant. Pearson correlation also showed a significant but low, positive relationship between root biomass and rootderived MBC. It is known that soil microbes acquire $\mathrm{C}$ (including root-derived $\mathrm{C}$ ) in the form of DOC in the soil solution (Smolander and Kitunen 2002; Montaño et al. 2007), and that quantity of root exudation in barley plants is closely correlated with root biomass production (Darwent et al. 2003). Thus, our results support the likely links between root-derived MBC and root biomass or root-derived DOC.

However, moderate and low correlations between root-derived $\mathrm{DOC}$ and $\mathrm{MBC}$ and root biomass and root-derived $\mathrm{MBC}$, respectively, suggest that rootderived MBC size was not mainly affected by root biomass size or DOC concentration. In previous work (Mwafulirwa et al. 2016), we showed that the activity (i.e. functional diversity) of soil microbes was affected by barley variety, likely due to differences in rhizodeposit quality (i.e. chemical composition) among the varieties or genotypes, which included genotypes 
used in the present study. This may lead us to assume that the variation in root-derived MBC observed here among the barley genotypes was also likely due to differences in rhizodeposit chemical composition among the genotypes, and that the marker effects for root-derived $\mathrm{MBC}$ or DOC revealed in this work were also associated with rhizodeposit composition. There are reports for QTLs and candidate genes influencing rhizodeposit chemical composition in other crop plants (Yan et al. 2004; Hongni et al. 2011; Qiu et al. 2014; Ramongolalaina et al. 2018). For instance, Hongni et al. (2011) mapped QTLs for three root exudates related to phosphorus efficiency in maize, while Yan et al. (2004) identified QTLs influencing root exudation of organic acids in common bean.

\section{Chromosome regions affecting root biomass}

Seven significant marker effects, on chromosomes $2 \mathrm{H}, 3 \mathrm{H}, 5 \mathrm{H}$ and $7 \mathrm{H}$, were identified for root biomass. Others have also reported the localization of QTLs influencing root biomass in barley on these chromosomes (reviewed by Sallam et al. 2019). For example, Naz et al. (2014) used the 1536-SNP barley BOPA1 set and detected a total of 13 QTLs for root dry weight and root volume using wild barley introgression lines (developed by crossing a German spring cultivar Scarlett and a wild accession ISR428), of which seven QTLs were located on chromosomes $2 \mathrm{H}, 3 \mathrm{H}, 5 \mathrm{H}$ and $7 \mathrm{H}$. Another study using barley lines genotyped using the Illumina 1536-SNP array (Arifuzzaman et al. 2014) also identified seven QTLs for root dry weight, with four of the QTLs localized on chromosomes $2 \mathrm{H}, 3 \mathrm{H}, 5 \mathrm{H}$ and $7 \mathrm{H}$. In particular, Arifuzzaman et al. (2014) detected a QTL on $2 \mathrm{H}$ spanning from 38.9 to $66.0 \mathrm{cM}$, corroborating our present study showing significant marker effects on the same chromosome region (38.1-53.8 cM in the present study). This correspondence with previous studies adds additional confidence in our identification of barley chromosome regions influencing $\mathrm{MBC}$ and DOC pools in soil.

\section{Conclusions}

Our study is the first to identify barley chromosome regions and potential candidate genes influencing $\mathrm{MBC}$ and DOC concentrations in soil, and thus microbial populations and $\mathrm{C}$ cycling in soil. In total, 16 chromosome regions were identified for rootderived $\mathrm{MBC}$ and DOC, mainly on chromosomes $2 \mathrm{H}, 3 \mathrm{H}$ and $7 \mathrm{H}$. Two locations on $3 \mathrm{H}$ influenced both traits (i.e. root-derived $\mathrm{MBC}$ and $\mathrm{DOC}$ ). In addition, one chromosome region on $4 \mathrm{H}$ with the wild barley genome decreased root-derived $\mathrm{MBC}$, and three on chromosomes $1 \mathrm{H}$ and $3 \mathrm{H}$ increased root-derived DOC, corroborating the observed phenotypes. This work also supports the previously detected QTLs for root biomass in barley, and therefore validating the chromosome regions influencing root-derived $\mathrm{MBC}$ and DOC. Thus, these findings are an important step towards better understanding of the plant genetic influences on soil microbial communities, which could be vital to control $\mathrm{C}$ and $\mathrm{N}$ cycling in soil through plant breeding approaches. Further work, for example using more replications, is needed to verify the barley chromosome regions or marker effects for $\mathrm{MBC}$ and $\mathrm{DOC}$ and potential candidate genes revealed in this study, and to sequence the soil microbes to examine the interaction between plant genotype and the diversity or structure of rhizosphere microbiomes.

Acknowledgements This work was supported by a James Hutton Institute international $\mathrm{PhD}$ studentship awarded to $\mathrm{L}$ Mwafulirwa. The James Hutton Institute and Biomathematics and Statistics Scotland receive funding from RESAS (Rural \& Environmental Science \& Analytical Services) of the Scottish Government. We are thankful to A Sim, B Thornton, G Martin, M Procee, S McIntyre and M Giles for their respective contributions towards this paper. We also acknowledge P Hayes and I Matus for supplying the original set of the barley RCSLs.

Author contributions All authors contributed to the planning of this research, while LM designed and performed the experiment. LM and CAH analysed data. LM, EMB, JR, CAH and EP wrote the manuscript.

Data availability The datasets generated during the current study are available from the corresponding author on request.

\section{Declarations}

Conflict of interest The authors declare no competing interests.

Open Access This article is licensed under a Creative Commons Attribution 4.0 International License, which permits use, sharing, adaptation, distribution and reproduction in any medium or format, as long as you give appropriate credit to the original author(s) and the source, provide a link to the Creative Commons licence, and indicate if changes were made. The images or other third party material in this article are included in the article's Creative Commons licence, unless indicated 
otherwise in a credit line to the material. If material is not included in the article's Creative Commons licence and your intended use is not permitted by statutory regulation or exceeds the permitted use, you will need to obtain permission directly from the copyright holder. To view a copy of this licence, visit http://creativecommons.org/licenses/by/4.0/.

\section{References}

Aira M, Gómez-Brandón M, Lazcano C et al (2010) Plant genotype strongly modifies the structure and growth of maize rhizosphere microbial communities. Soil Biol Biochem 42:2276-2281. https://doi.org/10.1016/j.soilbio.2010.08. 029

Alegria Terrazas R, Giles C, Paterson E et al (2016) Plantmicrobiota interactions as a driver of the mineral turnover in the Rhizosphere. Adv Appl Microbiol 95:1-67. https:// doi.org/10.1016/bs.aambs.2016.03.001

Arifuzzaman M, Sayed MA, Muzammil S et al (2014) Detection and validation of novel QTL for shoot and root traits in barley (Hordeum vulgare L.). Mol Breed 34:13731387. https://doi.org/10.1007/s11032-014-0122-3

Blagodatskaya EV, Blagodatsky SA, Anderson T-H, Kuzyakov Y (2009) Contrasting effects of glucose, living roots and maize straw on microbial growth kinetics and substrate availability in soil. Eur J Soil Sci 60:186-197. https://doi.org/10.1111/j.1365-2389.2008.01103.x

Bouffaud ML, Kyselková M, Gouesnard B et al (2012) Is diversification history of maize influencing selection of soil bacteria by roots? Mol Ecol 21:195-206

Cheng W, Johnson D, Fu S (2003) Rhizosphere effects on decomposition: controls of plant species, phenology, and fertilization. Soil Sci Soc Am J 67:1418-1427

Cheng W, Kuzyakov Y (2005) Root effects on soil organic matter decomposition. American Society of Agronomy, Crop Science Society of America, Soil Science Society of America, Madison, pp 119-143

Close TJ, Bhat PR, Lonardi S et al (2009) Development and implementation of high-throughput SNP genotyping in barley. BMC Genomics 10:582. https://doi.org/10.1186/ 1471-2164-10-582

Comadran J, Kilian B, Russell J et al (2012) Natural variation in a homolog of Antirrhinum CENTRORADIALIS contributed to spring growth habit and environmental adaptation in cultivated barley. Nat Genet 44:13881391. https://doi.org/10.1038/ng.2447

Darwent MJ, Paterson E, McDonald AJS, Tomos AD (2003) Biosensor reporting of root exudation from Hordeum vulgare in relation to shoot nitrate concentration. J Exp Bot 54:325-334. https://doi.org/10.1093/jxb/erg017

De la Fuente CC, Russell J, Hackett CA et al (2018) Genetic dissection of quantitative and qualitative traits using a minimum set of barley recombinant chromosome substitution lines. BMC Plant Biol 18:1-20. https://doi.org/ 10.1186/s12870-018-1527-7

Dijkstra FA, Carrillo Y, Pendall E, Morgan JA (2013) Rhizosphere priming: a nutrient perspective. Front Microbiol 4:216. https://doi.org/10.3389/fmicb.2013.00216

Dos Santos AL, Chaves-Silva S, Yang L et al (2017) Global analysis of the MATE gene family of metabolite transporters in tomato. BMC Plant Biol 17:185. https:// doi.org/10.1186/s12870-017-1115-2

Fontaine S, Henault C, Aamor A et al (2011) Fungi mediate long term sequestration of carbon and nitrogen in soil through their priming effect. Soil Biol Biochem 43:8696. https://doi.org/10.1016/j.soilbio.2010.09.017

Gahoonia TS, Nielsen NE (2004) Root traits as tools for creating phosphorus efficient crop varieties. Plant Soil 260:47-57

Garcia-Pausas J, Paterson E (2011) Microbial community abundance and structure are determinants of soil organic matter mineralisation in the presence of labile carbon. Soil Biol Biochem 43:1705-1713. https://doi.org/10. 1016/j.soilbio.2011.04.016

Garnett T, Conn V, Kaiser BN (2009) Root based approaches to improving nitrogen use efficiency in plants. Plant Cell Environ 32:1272-1283. https://doi.org/10.1111/j.13653040.2009.02011.x

Hongni Q, Yi-Lin C, Hai-Yan S et al (2011) QTL mapping of root exudates related to phosphorus efficiency in maize (Zea mays L.). J Agric Biotechnol 19:93-101

Janiak A, Kwasniewski M, Sowa M et al (2019) Insights into barley root transcriptome under mild drought stress with an emphasis on gene expression regulatory mechanisms. Int J Mol Sci 20:6139. https://doi.org/10.3390/ijms202461 39

Jenkinson DS, Fox RH, Rayner JH (1985) Interactions between fertilizer nitrogen and soil nitrogen-the so-called 'priming' effect. J Soil Sci 36:425-444. https://doi.org/10. 1111/j.1365-2389.1985.tb00348.x

Joergensen RG (1996) The fumigation-extraction method to estimate soil microbial biomass: calibration of the kEC value. Soil Biol Biochem 28:25-31. https://doi.org/10. 1016/0038-0717(95)00102-6

Jones DL, Hodge A, Kuzyakov Y (2004) Plant and mycorrhizal regulation of rhizodeposition. New Phytol 163:459-480. https://doi.org/10.1111/j.1469-8137.2004.01130.x

Julius BT, Leach KA, Tran TM et al (2017) Sugar transporters in plants: new insights and discoveries. Plant Cell Physiol 58:1442-1460. https://doi.org/10.1093/pcp/pcx090

Kuzyakov Y, Friedel JK, Stahr K (2000) Review of mechanisms and quantification of priming effects. Soil Biol Biochem 32:1485-1498

Li Y, Zhou R, Branlard G, Jia J (2010) Development of introgression lines with 18 alleles of glutenin subunits and evaluation of the effects of various alleles on quality related traits in wheat (Triticum aestivum L.). J Cereal Sci 51:127-133. https://doi.org/10.1016/j.jcs.2009.10.008

Li LJ, Han XZ, You MY et al (2013) Carbon and nitrogen mineralization patterns of two contrasting crop residues in a mollisol: effects of residue type and placement in soils. Eur J Soil Biol 54:1-6. https://doi.org/10.1016/j.ejsobi. 2012.11.002

Marschner H (1995) Mineral nutrition of higher plants, 2nd edn. Academic Press, London

Mascher M, Gundlach H, Himmelbach A et al (2017) A chromosome conformation capture ordered sequence of the barley genome. Nature 544:427-433. https://doi.org/10. 1038/nature22043

Matus I, Corey A, Filichkin T et al (2003) Development and characterization of recombinant chromosome substitution 
lines (RCSLs) using Hordeum vulgare subsp. spontaneum as a source of donor alleles in a Hordeum vulgare subsp. vulgare background. Genome 46:1010-1023. https://doi. org/10.1139/g03-080

Montaño NM, García-Oliva F, Jaramillo VJ (2007) Dissolved organic carbon affects soil microbial activity and nitrogen dynamics in a Mexican tropical deciduous forest. Plant Soil 295:265-277. https://doi.org/10.1007/ s11104-007-9281-x

Mwafulirwa L, Baggs EM, Russell J et al (2016) Barley genotype influences stabilization of rhizodeposition-derived C and soil organic matter mineralization. Soil Biol Biochem 95:60-69. https://doi.org/10.1016/j.soilbio.2015.12.011

Mwafulirwa LD, Baggs EM, Russell J et al (2017) Combined effects of rhizodeposit $\mathrm{C}$ and crop residues on SOM priming, residue mineralization and $\mathrm{N}$ supply in soil. Soil Biol Biochem 113:35-44. https://doi.org/10.1016/j.soilbio. 2017.05.026

Mwafulirwa L, Paterson E, Cairns JE et al (2021) Genotypic variation in maize (Zea mays) influences rates of soil organic matter mineralization and gross nitrification. New Phytol. https://doi.org/10.1111/NPH.17537

Naz AA, Arifuzzaman M, Muzammil S et al (2014) Wild barley introgression lines revealed novel QTL alleles for root and related shoot traits in the cultivated barley (Hordeum vulgare L.). BMC Genet 15:107. https://doi. org/10.1186/s12863-014-0107-6

Paterson E (2003) Importance of rhizodeposition in the coupling of plant and microbial productivity. Eur J Soil Sci 54:741750. https://doi.org/10.1046/j.1351-0754.2003.0557.x

Paterson E, Osler G, Dawson LA et al (2008) Labile and recalcitrant plant fractions are utilised by distinct microbial communities in soil: Independent of the presence of roots and mycorrhizal fungi. Soil Biol Biochem 40:1103-1113. https://doi.org/10.1016/j.soilbio.2007. 12.003

Patterson JA, Tetlow IJ, Emes MJ (2018) Bioinformatic and in vitro analyses of Arabidopsis starch synthase 2 reveal post-translational regulatory mechanisms. Front Plant Sci 9:1338. https://doi.org/10.3389/fpls.2018.01338

Paul MJ, Gonzalez-Uriarte A, Griffiths CA, Hassani-Pak K (2018) The role of trehalose 6-phosphate in crop yield and resilience. Plant Physiol 177:12-23

Paul MJ, Watson A, Griffiths CA (2020) Trehalose 6-phosphate signalling and impact on crop yield. Biochem Soc Trans 48:2127-2137

Pausch J, Loeppmann S, Kühnel A et al (2016) Rhizosphere priming of barley with and without root hairs. Soil Biol Biochem 100:74-82. https://doi.org/10.1016/j.soilbio. 2016.05.009

Peiffer JA, Spor A, Koren O et al (2013) Diversity and heritability of the maize rhizosphere microbiome under field conditions. Proc Natl Acad Sci USA 110:6548-6553. https://doi.org/10.1073/pnas.1302837110

Prentice I, Farquhar G, Fasham M et al (2001) The carbon cycle and atmospheric carbon dioxide. In: Houghton JT, Ding Y, Griggs DJ et al (eds) Climate change: the scientific basis. Cambridge University Press, Cambridge, pp 183-237

Prudent M, Causse M, Gé Nard M et al (2009) Genetic and physiological analysis of tomato fruit weight and composition: influence of carbon availability on QTL detection. J Exp Bot 60:923-937. https://doi.org/10.1093/ jxb/ern338

Qiu H, Liu C, Yu T et al (2014) Identification of QTL for acid phosphatase activity in root and rhizosphere soil of maize under low phosphorus stress. Euphytica 197:133-143. https://doi.org/10.1007/s10681-013-1058-0

Ramongolalaina C, Teraishi M, Okumoto Y (2018) QTLs underlying the genetic interrelationship between efficient compatibility of Bradyrhizobium strains with soybean and genistein secretion by soybean roots. PLoS ONE 13:e0194671. https://doi.org/10.1371/journal.pone.01946 71

Sallam A, Alqudah AM, Dawood MFA et al (2019) Drought stress tolerance in wheat and barley: advances in physiology, breeding and genetics research. Int J Mol Sci 20:3137

Schmalenbach I, Léon J, Pillen K (2009) Identification and verification of QTLs for agronomic traits using wild barley introgression lines. Theor Appl Genet 118:483-497. https://doi.org/10.1007/S00122-008-0915-Z

Shahzad T, Chenu C, Genet P et al (2015) Contribution of exudates, arbuscular mycorrhizal fungi and litter depositions to the rhizosphere priming effect induced by grassland species. Soil Biol Biochem 80:146-155. https://doi.org/ 10.1016/j.soilbio.2014.09.023

Smolander A, Kitunen V (2002) Soil microbial activities and characteristics of dissolved organic $\mathrm{c}$ and $\mathrm{n}$ in relation to tree species. Soil Biol Biochem 34:651-660. https://doi. org/10.1016/S0038-0717(01)00227-9

Tanksley SD, McCouch SR (1997) Seed banks and molecular maps: unlocking genetic potential from the wild. Science 277:1063-1066. https://doi.org/10.1126/science.277. 5329.1063

Tian J, Fan M, Guo J et al (2012) Effects of land use intensity on dissolved organic carbon properties and microbial community structure. Eur J Soil Biol 52:67-72. https:// doi.org/10.1016/j.ejsobi.2012.07.002

Tripodi P, Vitiello A, D'Onofrio B et al (2020) Dissecting the genotypic and environmental factors underpinning the quantitative trait variation in a set of wild tomato (Solanum habrochaites LA1777) introgression lines. Agronomy 11:38. https://doi.org/10.3390/agronomy 11010038

Vance ED, Brookes PC, Jenkinson DS (1987) An extraction method for measuring soil microbial biomass C. Soil Biol Biochem 19:703-707. https://doi.org/10.1016/00380717(87)90052-6

Walters WA, Jin Z, Youngblut N et al (2018) Large-scale replicated field study of maize rhizosphere identifies heritable microbes. Proc Natl Acad Sci USA 115:7368-7373. https://doi.org/10.1073/pnas.1800918115

White P, Bengough A, Bingham I, et al (2009) Induced mutations affecting root architecture and mineral acquisition in barley. In QY Shu (ed.), Induced plant mutations in the genomics era. In: Food Agric. Organ. United Nations. http://www.fao.org/3/i0956e/I0956e.pdf. Accessed 8 Feb 2021

Wissuwa M, Mazzola M, Picard C (2009) Novel approaches in plant breeding for rhizosphere-related traits. Plant Soil 321:409-430

Yan X, Liao H, Beebe SE et al (2004) QTL mapping of root hair and acid exudation traits and their relationship to 
phosphorus uptake in common bean. Plant Soil 265:1729. https://doi.org/10.1007/s11104-005-0693-1

Yin L, Corneo PE, Richter A et al (2019) Variation in rhizosphere priming and microbial growth and carbon use efficiency caused by wheat genotypes and temperatures. Soil Biol Biochem 134:54-61. https://doi.org/10.1016/j.soilb io.2019.03.019
Publisher's note Springer Nature remains neutral with regard to jurisdictional claims in published maps and institutional affiliations. 